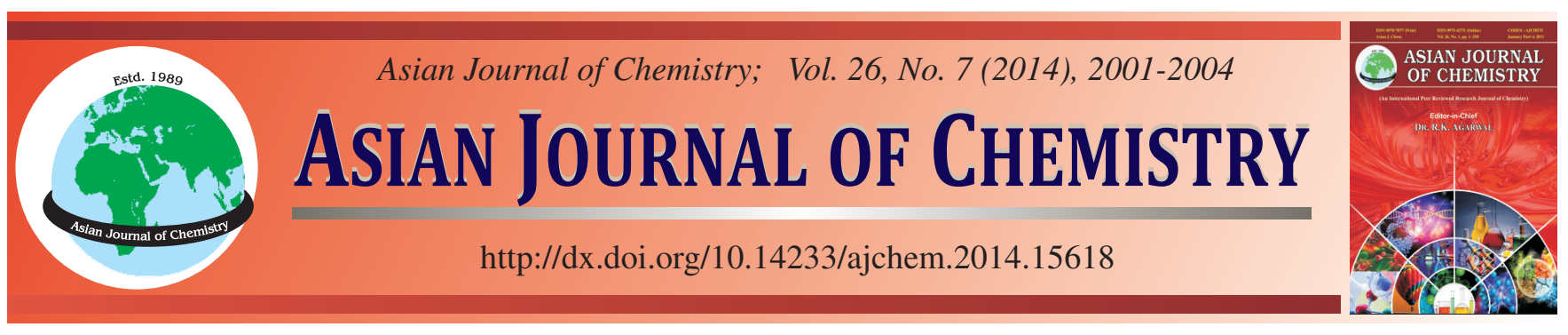

\title{
Chemical Composition and Antimicrobial Activity of Essential Oils from Tortella inclinata var. Densa, T. tortusa and Pleurochaete squarrosa
}

Gonca Tosun ${ }^{1}$, Büsra Yayli ${ }^{1}$, Turan ÖZdemir ${ }^{2}$, NevZat Batan $^{2}$, Nurettin Yayli $^{3, *}$ and Sengül Alpay Karaoglu ${ }^{4}$

${ }^{1}$ Department of Chemistry, Karadeniz Technical University, 61080, Trabzon, Turkey

${ }^{2}$ Department of Biology, Karadeniz Technical University, 61080, Trabzon, Turkey

${ }^{3}$ Faculty of Pharmacy, Karadeniz Technical University, 61080, Trabzon, Turkey

${ }^{4}$ Department of Biology, Faculty of Science and Arts, Rize University, 53100 Rize, Turkey

*Corresponding author: Fax: +90 462 3256717; Tel: +90 462 3778801; E-mail: yayli@ktu.edu.tr

\begin{abstract}
Although some chemical compositional data are available about the extracts of Tortella tortusa and Pleurochaete squarrosa, there is no investigation about the compositions and antimicrobial activities of the volatiles from Tortella inclinata var. densa, Tortella tortusa and Pleurochaete squarrosa. Thus, the essential oils of these mosses were isolated by hydrodistillation and then characterised by GC-FID/ MS. A total of 13, 33 and 40 compounds were identified, constituting over 93.8, 99.4 and $88.6 \%$, respectively. The essential oils consisted mainly of aldehydes $(39.0 \%, 33.2 \%$ and $48.9 \%)$, monoterpenes $(0.0,15.5$ and $8.5 \%)$ and hydrocarbons $(48.6,32.0$ and $12.9 \%)$. The major compound of all three essential oils was nonanal (14.8, 9.1 and $24.6 \%$, respectively). In addition, the antibacterial activities were investigated and the essential oils showed antimicrobial and antifungal activities against Staphylococcus aureus, Enterococcus faecalis, Bacillus cereus, Mycobacterium smegmatis, Candida albicans and Saccharomyces cerevisiae with MIC values in the range of $405-4650 \mu \mathrm{g} / \mu \mathrm{L}$. Essential oils of all three mosses showed moderate antituberculosis activity against M. Smegmatis $(405-1163 \mu \mathrm{g} / \mu \mathrm{L})$.
\end{abstract}

Keywords: Tortella inclinata var. densa, Tortella tortusa, Pleurochaete squarrosa, Antimicrobial and antituberculosis activity.

\section{INTRODUCTION}

Bryophytes, which are phylogenetically placed between vascular plants and algae, form a unique division in the plant kingdom ${ }^{1}$. There exist more than 22,000 members of mosses (Bryophyta) in the world. This figure represents $5.5 \%$ of the 400,000 plant types spread throughout the world ${ }^{2}$.

The Pottiaceae form the most numerous moss family known and member of the Bryophytes, containing nearly 1500 species or more than $10 \%$ of the 10000 to 15000 moss species $^{3}$. It is extensively spread in the world in considerably variable environments, basically in temperate and mountainous regions. Notably, many of them adapted to arid climates and they are often the dominant mosses in dry area of the world.

In Turkey, the genera Tortella and Pleurochaete are related to Pottiaceae family represented by 8 and 2 taxa, respectively. As a result of our literature search, no published record has been found for the volatile chemical composition and antimicrobial activity of the essential oils of $T$. inclinata var. densa, T. tortusa and $P$. squarrosa.

Bryophytes are reported to be rich in phenolics (flavonoids and bibenzyl derivatives), glycosides, fatty acids, terpenoids and some rare aromatic compounds ${ }^{4-8}$. Less studies concerning the chemical compositions of essential oils and biological activity of bryophytes have been published ${ }^{9}$. With the abundance of volatile aldehydes and terpenoids, mosses recently attracted compositional interest ${ }^{10}$. Although the earlier reports mention absence or only trace presence of terpenoids ${ }^{11}$, recent investigations showed the occurrences of a great variety of terpenes and aliphatic and aromatic aldehydes ${ }^{10}$.

The aim of this work is to do a compositional analysis of the essential oils isolated from the mentioned three mosses originating from Turkey. We also determined the antimicrobial activity of the essential oils against a panel of seven bacterial and two fungal strains.

\section{EXPERIMENTAL}

T. inclinata var. densa, T. tortusa and P. squarrosa were collected in Maçka, Trabzon, (at heights of 1314 m, 1130 m and $235 \mathrm{~m}$, respectively), southeastern part of Turkey in May, 2012. The mosses were authenticated by Turan Özdemir ${ }^{12}$. Voucher specimens were deposited in the Herbarium of the Department of Biology (Özdemir and Batan 1511, 1512 and 1513, respectively), Karadeniz Technical University, Turkey. 
Hydrodistillation apparatus and procedure: The fresh plant materials were separated and cut into small pieces. Essential oils of T. inclinata var. densa, T. tortusa and P. squarro were obtained from the fresh mosses ( $90 \mathrm{~g}$ each) by hydrodistillation in a modified Clevenger type apparatus with cooling bath $\left(-12{ }^{\circ} \mathrm{C}\right)$ system $(4 \mathrm{~h})$ [yields: $0.011 \%, 0.013 \%$ and $0.01 \%(\mathrm{v} / \mathrm{w})$, respectively]. The obtained oils were dissolved in HPLC grade $n$-hexane $(0.5 \mathrm{~mL})$, dried over anhydrous sodium sulfate and stored at $4-6{ }^{\circ} \mathrm{C}$ in sealed brown vial. Two $\mu \mathrm{L}$ of the essential oils was directly injected into GC-FID/MS instrument.

GC and GC/MS: The capilary GC-FID and GC-MS analyses were performed using Agilent-5973 Network System, equipped with an FID (supplied with air and hydrogen of high purity) and a split inlet. A mass spectrometer with an ion trap detector in full scan mode under electron impact ionization $(70 \mathrm{eV})$ was used. The chromatographic column used for the analysis was HP-5 capillary column $(30 \mathrm{~m} \times 0.32 \mathrm{~mm}$ i.d., film thickness $0.25 \mu \mathrm{m})$. Hellium was used as carrier gas, at a flow rate of $1 \mathrm{~mL} \mathrm{~min}{ }^{-1}$. The injections were performed in splitless mode at $230{ }^{\circ} \mathrm{C}$. Two $\mu \mathrm{L}$ essential oil solution in hexane (HPLC grade) was injected and analysed with the column held initially at $60{ }^{\circ} \mathrm{C}$ for $2 \mathrm{~min}$ and then increased to $240{ }^{\circ} \mathrm{C}$ with a $3{ }^{\circ} \mathrm{C} \mathrm{min}^{-1}$ heating ramp. The sample was analyzed twice and the percentage composition of oil was computed from the GC peak areas without using correction factors.

Identification of constituents: Retention indices of all the components were determined by Kovats method using $n$ alkanes $\left(\mathrm{C}_{5}-\mathrm{C}_{32}\right)$ as standards. The constituents of the oils were identified by comparison of their mass spectra with those of mass spectral libraries (NIST and Wiley), authentic compounds ( $\beta$-pinene, limonene, eicosane, docosane, tricosane and pentacosane) and with data published in the literature ${ }^{13}$.

Antimicrobial activity assessment: All test microorganisms were obtained from Hifzissihha Institute of Refik Saydam (Ankara, Turkey) and were as follows: Gram-negative (Escherichia coli ATCC35218, Yersinia pseudotuberculosis ATCC911, Pseudomonas aeruginosa ATCC43288), Grampositive (Enterococcus faecalis ATCC29212, Staphylococcus aureus ATCC25923, Bacillus cereus 709 Roma), Acidoresistant bacteria (Mycobacterium smegmatis ATCC607) and Yeast-like fungi (Candida albicans ATCC60193, Saccharomyces cerevisiae RSKK 251). The essential oil samples were dissolved in hexane to prepare stock solutions of 9.300-32.400 $\mu \mathrm{g} / \mathrm{mL}$

Agar dilution MIC assay: The antimicrobial effects of the samples were tested quantitatively in respective broth media by using double microdilution and the minimal inhibition concentration (MIC) values $(\mu \mathrm{g} / \mathrm{mL})$ were determined ${ }^{14}$. The antibacterial and antifungal assays were performed in MuellerHinton broth $(\mathrm{MH})$ (Difco, Detroit, $\mathrm{MI})$ at pH.7.3 and buffered Yeast Nitrogen Base (Difco, Detroit, MI) at pH 7.0, respectively. The micro dilution test plates were incubated for 18$24 \mathrm{~h}$ at $35^{\circ} \mathrm{C}$. Brain Heart Infusion broth (BHI) (Difco, Detriot, MI) was used for $M$. smegmatis and incubated for 48-72 h at $35{ }^{\circ} \mathrm{C}^{15}$. The MIC was defined as the lowest concentration that showed no growth. Ampicillin (stock conc. $10000 \mu \mathrm{g} /$ $\mathrm{mL}$ ), streptomycin (stock conc. $10000 \mu \mathrm{g} / \mathrm{mL}$ ) and fluconazole (stock conc. $2000 \mu \mathrm{g} / \mathrm{mL}$ ) were used as standard antibacterial and antifungal drugs, respectively. Dimethylsulphoxide with a dilution of 1:10 was used as solvent control. The results are shown in Table-2.

\section{RESULTS AND DISCUSSION}

The chemical composition of the essential oils obtained from the fresh parts of $T$. inclinata var. densa, T. tortusa and $P$. squarrosa are presented in Table-1. Altogether, fifty essential oil compounds were identified by GC-FID and GC-MS with HP-5 column ${ }^{13}$. Volatiles of most mosses have been shown to be abundant in aliphatic and aromatic aldehydes ( $n$-heptanal, $n$-nonanal, 2E,4E-decadienal, benzaldehyde and benzene acetaldehyde $)$ and hydrocarbons $\left(\mathrm{C}_{12}-\mathrm{C}_{18}\right.$, saturated, mono- and di-unsaturated) in many of the investigations reported ${ }^{16-19}$. We observed similar profiles for the all three investigated mosses. Nonanal (24.6, 9.1 and 14.8\%) and eicosane (27.2, 15.7 and $7.7 \%$ ) were found as the major compounds, which can be used as a marker for the mosses. Thirteen compounds were identified from the essential oil of T. inclinata var. densa, representing $93.8 \%$ of the total essential oil and eicosane $(27.2 \%)$, nonanal $(14.8 \%)$, undecanal $(7.7 \%)$ and 3-octanone $(2.3 \%)$ were the major components. In the essential oil of T. tortusa, 33 components were identified, representing $99.4 \%$ of the essential oil and eicosane (15.7\%), nonanal (9.1\%), heptanal $(8.3 \%)$ and $\alpha$-pinene $(4.4 \%)$ were the main constituents. Forty components were identified from the oil of P. squarrosa, representing $88.6 \%$ of the total oil and the major compounds were nonanal (24.6\%), heptanal (12.2\%), eicosane $(7.7 \%)$, octanal $(3.8 \%)$ and 3-octanone $(2.6 \%)$.

To the best of our knowledge, no previous report is found dealing with any investigation on the chemical constituents or biological activities of the essential oils of $T$. inclinata var. densa, T. tortusa and P. squarrosa mosses. The comparison of our data with those reported in the literature about other moss species showed that the main constituents of the investigated $P$. squarrosa oil are markedly different. The difference in composition of the oil may be attributed to the climate, environmental factors and geographical origin.

The antimicrobial activities of the isolated essential oils of T. inclinata var. densa, T. tortusa and P. Squarrosa were tested in vitro against the Gram-positive, Gram-negative, acido-resistant bacteria and fungal microorganisms. The antimicrobial activity with the essential oil of $T$. inclinata var. densa, T. tortusa and $P$. squarrosa were observed against the bacteria $Y$. pseudotuberculosis, $P$. aeruginosa, S. aureus, E. faecalis, B. cereus, M. smegmatis and the fungi $C$. albicans and $S$. cerevisiae. Antimicrobial activities of the samples against the studied bacteria were qualitatively and quantitatively assessed by evaluating the presence and the extent of minimal inhibitory concentration (MIC) values and the results are reported in Table-2. Pervious reports about antifungal and antibacterial activities of the extracts from $T$. tortus $a$ and $P$. squarros $a^{20}$ showed no activity against $B$. subtilis, Salmonella, $S$. aureus and $P$. aeruginosa. In our work, essential oils of $T$. tortusa and $P$. squarrosa showed moderate antimicrobial activity against the Gram positive bacteria $S$. aureus, E. faecalis, $B$. cereus, $M$. smegmatis and the fungi $C$. albicans and $S$. cerevisiae. The essential oils showed no antibacterial activity 


\begin{tabular}{|c|c|c|c|c|c|c|}
\hline $\begin{array}{r}\text { IDEN } \\
\text { ESSE }\end{array}$ & $\begin{array}{l}\text { PONENTS AN } \\
\text { OF } T \text {. inclinat }\end{array}$ & $\begin{array}{l}\text { LE-1 } \\
\text { HEMICAL CI } \\
\text { r. densa, T. tor }\end{array}$ & $\begin{array}{l}\text { IFICATION O } \\
\text { AND } P . \text { squar }\end{array}$ & & & \\
\hline Compounds & A Area $^{a}(\%)$ & B Area $^{a}(\%)$ & C Area ${ }^{a}(\%)$ & Ex.RI ${ }^{b}$ & & Lit. RI \\
\hline Heptanal & - & 8.3 & 12.2 & 900 & & 902 \\
\hline$\alpha$-Pinene & - & 4.4 & 2.4 & 937 & & 939 \\
\hline Camphene & - & 0.6 & 0.3 & 949 & & 954 \\
\hline Thuja-2,4 (10)-diene & - & - & 0.3 & 955 & & 960 \\
\hline Benzaldehyde & 1.1 & 1.3 & 0.8 & 958 & & 960 \\
\hline Sabinene & - & 0.1 & 0.2 & 970 & & 975 \\
\hline$\beta$-Pinene ${ }^{c}$ & - & 3.8 & 1.1 & 974 & & 979 \\
\hline 3-Octanone & 2.3 & 3.7 & 2.6 & 983 & & 984 \\
\hline 2-Amyl furan & 3.9 & 1.2 & 2.3 & 988 & & 991 \\
\hline 2E, 4E-Heptadienal & 1.5 & 0.8 & - & 992 & & MS-1 \\
\hline Octanal & - & 2.3 & 3.8 & 997 & & 999 \\
\hline$p$-Mentha-1 (7) 8-diene & - & 3.4 & - & 1004 & & 1004 \\
\hline$\alpha$-Terpinene & - & - & 0.2 & 1012 & & 1017 \\
\hline$p$-Cymene & - & - & 2.3 & 1020 & & 1025 \\
\hline$o$-Cymene & - & 0.3 & 0.8 & 1021 & & 1026 \\
\hline Limonene $^{c}$ & - & 1.4 & - & 1027 & & 1029 \\
\hline Benzene acetaldehyde & 7.0 & 4.3 & 2.5 & 1042 & & 1042 \\
\hline Octenal & 1.7 & - & - & 1057 & & MS-2 \\
\hline $\boldsymbol{\gamma}$-Terpinene & - & 1.5 & 0.9 & 1058 & & 1060 \\
\hline Nonanal & 14.8 & 9.1 & 24.6 & 1101 & & 1101 \\
\hline$\alpha$-Campholenal & - & - & 0.4 & 1124 & & 1126 \\
\hline Veratrole & - & - & 0.8 & 1146 & & 1146 \\
\hline 2E-Nonenal & - & - & - & 1160 & & 1162 \\
\hline Pinocarvone & - & 2.1 & 0.7 & 1157 & & 1165 \\
\hline 1,3-dimethoxybenzene & - & 0.3 & 0.8 & 1166 & & 1169 \\
\hline$p$-Methyl acetophenone & - & 0.9 & 0.5 & 1179 & & 1183 \\
\hline Myrtenal & - & 1.2 & 0.6 & 1189 & & 1196 \\
\hline Decanal & 2.4 & 2.8 & 2.4 & 1197 & & 1202 \\
\hline 2E-Decanal & - & 1.4 & 0.7 & 1255 & & 1264 \\
\hline Bornyl acetate & - & 0.6 & - & 1285 & & 1289 \\
\hline 2E,4Z-Decadienal & - & - & 0.5 & 1284 & & 1293 \\
\hline Undecanal & 7.7 & 2.6 & - & 1296 & & 1307 \\
\hline 2E,4E-Decadienal & 2.8 & 1.6 & 1.0 & 1310 & & 1317 \\
\hline Longifolene & - & - & 0.2 & 1402 & & 1408 \\
\hline Sesquithujene & - & 0.4 & - & 1415 & & 1417 \\
\hline$\alpha$-Guaiene & - & - & 2.4 & 1435 & & 1440 \\
\hline Cuparene & - & - & 0.2 & 1500 & & 1505 \\
\hline cis-calamenene & - & - & 0.2 & 1540 & & 1540 \\
\hline$\alpha$-Calacorene & - & - & 0.5 & 1540 & & 1546 \\
\hline Germacrene B & - & - & 0.7 & 1555 & & 1561 \\
\hline Tetradecanol & - & 4.5 & 2.1 & 1670 & & 1673 \\
\hline Pentadecanol & - & - & 0.3 & 1770 & & 1774 \\
\hline 1-Octadecene & - & - & 0.4 & 1785 & & 1790 \\
\hline Hexahydrofarnesyl acetone & - & 1.8 & 2.4 & 1840 & & 1847 \\
\hline Cyclohexadecanolide & - & 2.0 & - & 1930 & & 1935 \\
\hline Cembrene & - & - & 1.0 & 1935 & & 1939 \\
\hline Eicosane $^{c}$ & 27.2 & 15.7 & 7.7 & 2000 & & 2000 \\
\hline Docosane $^{c}$ & - & 1.6 & - & 2200 & & 2200 \\
\hline Tricosane $^{c}$ & 11.9 & 7.8 & 2.6 & 2300 & & 2300 \\
\hline \multirow[t]{3}{*}{ Pentacosane $^{c}$} & 9.5 & 6.9 & 2.2 & 2500 & & 2500 \\
\hline & & & & \multicolumn{3}{|c|}{ N.C ${ }^{d}$} \\
\hline & & & & $\mathrm{A}$ & $\mathrm{B}$ & $\mathrm{C}$ \\
\hline Monoterpenes & - & 15.5 & 8.5 & - & 8 & 9 \\
\hline Monoterpenoids & 2.3 & 7.6 & 3.9 & 1 & 4 & 3 \\
\hline Sesquiterpenes & - & 0.4 & 4.2 & - & 1 & 6 \\
\hline Diterpene & - & - & 1.0 & - & - & 1 \\
\hline Terpenoids related & - & 3.8 & 2.4 & - & 2 & 1 \\
\hline Hydrocarbons & 48.6 & 32.0 & 12.9 & 3 & 4 & 4 \\
\hline Aldehydes & 39.0 & 33.2 & 48.9 & 8 & 10 & 10 \\
\hline Others & 3.9 & 6.9 & 6.8 & 1 & 4 & 6 \\
\hline Total isolate & 93.8 & 99.4 & 88.6 & 13 & 33 & 40 \\
\hline
\end{tabular}

A: T. inclinata var. densa, B: T. tortusa, C: P. squarrosa; ${ }^{a} \mathrm{RI}$ calculated from retention times relative to that of $n$-alkanes $\left(\mathrm{C}_{5}\right.$ - $\left.\mathrm{C}_{32}\right)$ on the non-polar HP-5 column. ${ }^{b}$ Percentages obtained by FID peak-area normalisation. 'Identified by authentic samples. ${ }^{\mathrm{d}} \mathrm{NC}$ : Number of compounds. MS-1: 110(15), 83(80), 81(100), 77(10), 67(15), 53(25). MS-2: 97(15), 83(85), 70(80), 67(35), 57(55), 55(100) 


\begin{tabular}{|c|c|c|c|c|c|c|c|c|c|c|}
\hline \multirow{3}{*}{ Sample } & \multicolumn{9}{|c|}{$\begin{array}{c}\text { TABLE-2 } \\
\text { SCREENING RESULTS FOR ANTIMICROBIAL ACTIVITY OF ESSENTIAL } \\
\text { OILS FROM T. inclinata var. densa, } T \text {. tortusa, and } P \text {. squarrosa }\end{array}$} & \\
\hline & \multirow{2}{*}{$\begin{array}{l}\text { Stock conc. } \\
(\mu \mathrm{g} / \mathrm{mL})\end{array}$} & \multicolumn{9}{|c|}{ Microorganisms and minimal inhibition concentration (MIC, $\mu \mathrm{g} / \mathrm{mL}$ ) } \\
\hline & & Ec & Yp & $\mathrm{Pa}$ & $\mathrm{Sa}$ & Ef & $\mathrm{Bc}$ & Ms & $\mathrm{Ca}$ & Sc \\
\hline A & 31500 & - & - & - & - & - & - & 788 & - & - \\
\hline B & 32400 & - & - & - & 1620 & 1620 & 1620 & 405 & - & - \\
\hline Ampicillin & 10000 & 2 & 32 & $>128$ & 2 & 2 & $<1$ & not tested & not tested & not tested \\
\hline Streptomycin & 10000 & not tested & not tested & not tested & not tested & not tested & not tested & 4 & not tested & not tested \\
\hline Fluconazole & 2000 & not tested & not tested & not tested & not tested & not tested & not tested & not tested & $<8$ & $<8$ \\
\hline
\end{tabular}

against the Gram-negative bacteria E. coli, Y. pseudotuberculosis and $P$. aeruginosa. However, the essential oil of $T$. inclinata var. densa showed antimicrobial activity only against $M$. smegmatis. The MIC values for bacterial strains were in the range from $405 \mu \mathrm{g} / \mathrm{mL}$ to $4650 \mu \mathrm{g} / \mathrm{mL}$ (Table-2).

\section{Conclusion}

In conclusion, the results of the analyses of essential oils from T. inclinata var. densa, T. tortusa and P. squarrosa show that although these three species are in the same family, only the compositional similarity were observed between $T$. tortusa and $P$. squarrosa. The essential oil from T. inclinata var. densa, T. tortusa and $P$. squarrosa showed a moderate antimicrobial activity against $M$. smegmati with MIC values in the range of $405-1163 \mu \mathrm{g} / \mu \mathrm{L}$.

\section{ACKNOWLEDGEMENTS}

This work was supported by grants from Karadeniz Technical University Research Fund (KTÜ-BAP 2010.11.004.7) of Turkey.

\section{REFERENCES}

1. A. Matsuo and A. Sato, Phytochemistry, 30, 2305 (1991).

2. H.D. Zinsmeister and R. Mues, Git Fachz. Lab., 31, 499 (1987).

3. W.R. Buck, B. Goffinet and A.J. Shaw, Mol. Phylogenet. Evol., 16, 180 (2000)

4. N. Jockovic, P.B. Andrade, P. Valentão and M. Sabovljevic, J. Serb. Chem. Soc., 73, 1161 (2008).

5. A. Sabovljevic, M. Sabovljevic and N. Jockovic, in eds.: S.M. Jain and P.K. Saxena, in vitro Culture and Secondary Metabolite Isolation in Bryophytes. Methods in Molecular Biology: Protocols for in vitro Cultures and Secondary Metabolite Analysis of Aromatic and Medicinal Plants, Humana Press, Humana Press, 547: pp. 117-128 (2009).

6. A. Sabovljevic, M. Sokovic, J. Glamoclija, A. Ciric, M. Vujicic and B. Pejin and M. Sabovljevic, Afr. J. Microbiol. Res., 4, 808 (2010).

7. H.D. Zinsmeister, R. Mues and G.I.T. Ingredients, Mag. Lab., 31, 499 (1987).

8. H.D. Zinsmeister, H. Becker and T. Eicher, Angew. Chem. Int. Ed. Engl., 30, 130 (1991).

9. F. Savaroglu, S. Ilhan and C. Filik-Iscen, J. Med. Plants Res., 5, 3286 (2011).

10. O. Üçüncü, T.B. Cansu, T. Özdemir, S.A. Karaoglu and N. Yayli, Turk. J. Chem., 34, 825 (2010).

11. Y. Saritas, M.M. Sonwa, H. Iznaguen, W.A. König, H. Muhle and R. Mues, Phytochemistry, 57, 443 (2001).

12. V.E. Fedosov and E.A. Ignatova, Arctoa, 18, 189 (2009).

13. R.P. Adams, Identification of Essential Oil Components by Gas Chromatography/Quadrupole Mass Spectroscopy, Carol Stream, IL: Allured Publication (2004).

14. Willanova, National Committee for Clinical Laboratory Standard, NCCLS, PA, M26-A, 19 (1999).

15. G.L. Woods, B.A. Brown-Elliott, E.P. Desmond, G.S. Hall, L. Heifets, G.E. Pfyffer, J.C. Ridderhof, R.J. Jr. Wallace, N.C. Warren and F.G. Witebsky, NCCLS document, M24-A, 23 (2003).

16. T. Özdemir, N. Yayli, T.B. Cansu, C. Volga and N. Yayli, Asian J. Chem., 21, 5505 (2009).

17. T.B. Cansu, O. Üçüncü, N. Kahriman, T. Özdemir and N. Yayli, Asian J. Chem., 22, 7280 (2010).

18. T. Özdemir, O. Üçüncü, T.B. Cansu, N. Kahriman and N. Yayli, Asian J. Chem., 22, 7285 (2010).

19. G. Tosun, N. Kahriman, C.G. Albay, S.A. Karaoglu and N. Yayli, Turk. J. Chem., 35, 145 (2011).

20. B. Elibol, T. Ezer, R. Kara, G.Y. Çelik and E. Çolak, Afr. J. Biotechnol., 10, 986 (2011). 